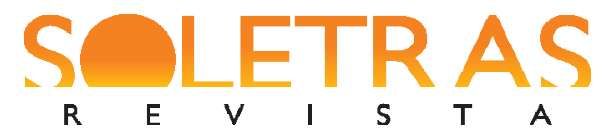

\section{PELO BURACO DA FECHADURA: autores e obras da literatura pornográfica luso-brasileiros (1890-1912)}

\author{
Natanael Duarte de Azevedo ${ }^{1}$
}

Resumo: O presente artigo tem por objetivo resgatar um tipo de escrita silenciado pela história da literatura, o ñomance para homensò, e alguns autores que fizeram circular obras pornográficas em livros e jornais no Brasil Oitocentista, além de reconhecer, na construção heteróclita desse cenário livreiro, no século XIX, a pluralidade de produções literárias e a diversidade das práticas de leituras. Essa literatura era um sucesso de vendas ao ponto que muitos outros impressores/livreiros se aventuraram nessa seara que descortinava os desejos mais íntimos dos leitores brasileiros de final de século XIX. Para tanto, nos apoiaremos nos postulados teóricos da História Cultural e nas pesquisas em textos primários que contribuem para construção da representação de uma comunidade leitora de fim do século XIX. Dessa forma, podemos contribuir com a construção da história da literatura e resgatar os sentidos dos termos utilizados para os romances pornográficos, além de indicarmos alguns livros do gênero, que circularam no Brasil de fim do século XIX e início do XX.

Palavras-chave: Literatura pornográfica. Literatura Oitocentista. Livros e autores esquecidos.

\title{
Introdução
}

A temática do amor e do erotismo está associada ao movimento romântico nas artes em geral e, muitas vezes, essa temática foi vista pela ótica da oposição, ou seja, o amor era visto como um sentimento sem pecado, terno, enquanto que o erotismo era um sentimento carnal, luxurioso (DEL PRIORI, 2011). Essa dicotomia estabelecida entre o sentimento e o desejo sexual serviu de mote para investigações e produções não apenas no campo das artes, mas também nas ciências médicas, em tratados jurídicos e religiosos, como também nas produções literárias do século XIX.

Se por um lado temos o amor por uma perspectiva idealizada $̈$ com a caracterização da exaltação da amada casta e frágil ï , tema de muitos romances que circularam e/ou foram produzidos no Brasil Oitocentista, por outro, deparamo-nos com uma grande produção, publicação e divulgação de uma literatura que atendia à demanda dos desejos e das curiosidades sexuais, pela ótica pornográfica, a qual era protagonizada por mulheres

\footnotetext{
${ }^{1}$ Doutor em Letras pelo Programa de Pós-Graduação em Letras (PPGL) da UFPB. Professor Adjunto da Universidade Federal Rural do Pernambuco e atua nos cursos de graduação das Engenharias na Unidade Acadêmica do Cabo de Santo Agostinho (UACSA/UFRPE) e no Programa de Pós-Graduação em História da UFRPE. PE, Cabo de Santo Agostinho, Brasil.E-mail: natanael.duarte.ufpb@hotmail.com.
} 
exuberantes, sedentas de desejo e instigadoras de prazer no imaginário popular.O deleite na leitura pornográfica não era um quadro estritamente masculino. Muitas mulheres no século XIX rompiam as regras e se entregavam às leituras assíduas de romances com a temática sexual (DEL PRIORI, 2005; 2011).

De acordo com Almeida (1981, p. 214), o verbete ñpornografiaò adquire o significado de ñi. Palavrão. 2. Pintura ou desenho em postura erótica. 3. Devassidão. 4. Linguagem mímica, atentatória do pudor. óAlém do de válvula, a pornografia colegial assumia aspectos fabulares, apologais, educativosô(Nava, Balão, 318)ò (grifo do autor). É importante destacar que apesar do dicionarista não mencionar o vocábulo ñeróticoò como significado de pornografia, iremos nos apoiar nessa possível sinonímia a partir da dificuldade clara, segundo Alexandrian (1993), de estabelecermos uma nítida diferença entre os termos.

\footnotetext{
Ninguém consegue explicar a diferença entre um e outro [pornografia e erótico]. E com razão: não há diferença. A pornografia é a descrição pura e simples dos prazeres da carne; o erotismo é essa mesma descrição revalorizada em função de uma ideia do amor ou da vida social. Tudo o que é erótico é necessariamente pornográfico, com alguma coisa a mais. (ALEXANDRIAN, 1993, p. 8).
}

Assim, alertamos ao leitor que ora trabalharemos com o termo p̃pornografiaò, ora com o termo ñeróticoò, pois, se nos colocarmos no cenário do início do século XX, não encontraremos uma distinção clara entre os dois termos. Se pensarmos, por exemplo, que ao erotismo cabe a descrição de uma ideia amorosa e social, nesse mesmo contexto uma obra como O primo Basílio (1878), de Eça de Queiroz, era considerada literatura pornográfica.

Ao tratarmos da pornografia, devemos pensar na sua apropriação em relação ao avanço do tempo. Hunt (1999) identifica três momentos cruciais de formação da pornografia na arte: $1^{\circ}$ ) $\mathrm{Na}$ Antiguidade greco-romana: o erotismo sempre esteve presente nas produções humanas como representação do desejo da carne; $2^{\circ}$ ) No Renascimento europeu: a pornografia é citada pelos estudiosos como ñprimeira fonte modernaò (HUNT, 1999, p. 25) a partir dos escritos de Pietro Arentino (século XVI); $3^{\circ}$ ) Na ascensão da imprensa no século XIX: a pornografia só assume o status de categoria literária e representação visual a partir do século XIX, quando ña cultura impressa possibilitou às massas a obtenção de escritos e ilustraçõesò (HUNT, 1999, p. 13), uma vez que ñseu significado político e cultural não pode ser separado de seu aparecimento como categoria de pensamento, representação e regulamentaçãoò(HUNT, 1999, p. 11), 


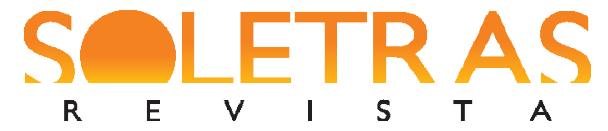

Optamos, assim, por investigar a circulação de livros e jornais em um período que vai do final do século XIX ao início do século XX porque, de acordo com estudiosos do século XIX no Brasil (EL FAR, 2010; DEL PRIORI, 2005; 2011), nesse momento houve grande produção, circulação e vendagem tanto dos jornais como de livros e, no caso específico da literatura pornográfica, as obras eróticas tiveram seu maior destaque durante esse período.

Nesse contexto editorial, surgiram também os ñromances para homensò, ou seja, as narrativas de teor pornográfico proibidas às mulheres, consideradas na época, pessoas de personalidade frágil e, portanto, suscetíveis aos enlevos amorosos do enredo. Esses romances ganharam um sem-número de leitores, que acompanhavam nos jornais os lançamentos de sucesso (EL FAR, 2010, p. 97).

Buscaremos, assim, reconhecer, na construção heteróclita desse cenário livreiro, no século XIX, a pluralidade de produções literárias e a diversidade das práticas de leituras, no que diz respeito à temática da pornografia, levando em consideração a relação entre obra e comunidade leitora.

É a partir de uma relação especular entre a obra e o leitor, que o texto literário passa a significar, ou seja, fazer sentido para um sujeito em particular. Sendo assim, entendemos que os pressupostos de estudiosos da História Cultural, como Michel de Certeau (2006; 2012), Pierre Bourdieu (2005) e Roger Chartier (1991; 1997; 2004) indicam que não basta ao texto literário existir, pois ele é materializado pelo sentido empreendido pelo sujeito leitor, ou seja, a apropriação do livro pelo leitor será responsável pela representação de sentido da obra e da sociedade na qual ela foi lida.

Por isso, colocamo-nos no lugar da investigação, pautada não na interpretação de obras literárias, da imanência do texto, mas da pesquisa que vê o tratamento investigativo dado ao livro a partir de três polos centrais para os estudos da história da literatura, segundo Chartier (1991, p. 178), que são: ño estudo crítico do texto, literários ou não, canônicos ou esquecidosò, ña história dos livros e, para além, de todos os objetos que contém a comunicação do escritoò, e, por fim, ña análise das práticas que, diversamente, se apreendem dos bens simbólicos, produzindo assim usos e significações diferenciadasò.

\section{Representação, apropriação e prática social: uma questão pornográfica}

O reconhecimento de uma comunidade leitora por meio de suas práticas, gestos, apropriação de leitura, requer um trabalho de investigação que considere todas as estratégias 
utilizadas para a concretização do ato de ler. Em outras palavras, entendemos que a pesquisa deve privilegiar não só o texto escrito e legitimado pela história, mas os diversos gêneros literários que circularam no Brasil Oitocentista, em especial, os ñomances para homensò. Ressaltamos que o gênero ñromance para homensò diz respeito à literatura pornográfica que circulou em potencial no período Oitocentista, chamando a atenção tanto dos leitores assíduos como dos livreiros que viram o lucro na produção de títulos dessa categoria. O termo ñomances para homensò é utilizado tanto por El Far (2004) quanto por Del Priori (2011) para se referir à literatura pornográfica que circulou em Portugal e no Brasil desde o século XVII, mas teve seu tempo de glória nas livrarias e pontos de vendas de livros luso-brasileiros a partir da segunda metade do século XIX.

O mesmo sucesso de circulação e vendagem é percebido nos periódicos que traziam em seus impressos tanto os gêneros eróticos e/ou pornográficos, como a divulgação de livros com a mesma temática. Vale salientar que vários impressores se valeram da divulgação não só das prateleiras, mas, principalmente, pelas chamadas ininterruptas dos periódicos acerca das obras obscenas, trazendo grandes lucros tanto para os editores como para os impressores, que em alguns casos tinham o apoio velado da polícia brasileira:

A. A. da Cruz Coutinho estabeleceu-se no Rio de Janeiro por volta de 1855. Nessa cidade, publicou alguma coisa de literatura brasileira, como, por exemplo, Gonzaga (1875), de Castro Alves, e a quinta edição de Espumas Flutuantes (1881), do mesmo autor, mas concentrou-se em publicações obscenas, protegido por uma força policial complacente e pelas ñfrouxas leis do Brasilò (HALLEWELL, 2005, p. 272).

O sucesso de vendas era tamanho que muitos outros impressores/livreiros se aventuraram nessa seara que descortinava os desejos mais íntimos dos leitores brasileiros de final de século XIX. Um outro personagem muito conhecido da história luso-brasileira do livro foi o livreiro Pedro Quaresma, que fundou a Livraria do Povo em 1879, no Rio de Janeiro, e atraiu um grande público para a aquisição de seus livros baratos, de fácil leitura, em especial, jovens escritores que faziam da livraria um ponto de encontro e leitura diária (HALLEWELL, 2005).

Quaresma abriu no fim da década de 1870 sua Livraria do Povo. Além de vender livros usados e algumas raridades bibliográficas, editou inúmeros romances, livros de trovas e cantigas e até mesmo os chamados ñromances para homensò, de teor picante e proibidos às moçoilas de boa família (EL FAR, 2010, p. 95). 
A escolha por esses gêneros literários se deu pela grande circulação que eles tiveram no Brasil do século XIX (EL FAR, 2004), e também pela possibilidade de apreendermos a representação da temática do amor e do/a erotismo/pornografia, uma vez que são modelos tanto da literatura cortês $\ddot{i}$ da arte de cortejar o amor da mulher pretendida $\ddot{i}$ como da pornografia que corria ñàs escurasò pelas mãos dos leitores.

Dessa forma, vemos que a apropriação da pornografia feita pelos autores dos ñomances para homensò se deu de forma heterogênea, uma vez que alguns romances privilegiam a obscenidade declarada, mas, em outros momentos do mesmo romance, há uma predileção pela sexualidade velada. Ressaltamos que o plural utilizado em ñautoresò não se dá apenas pela diversidade de escritores do gênero pornográfico, mas em sua acepção mais ampla, segundo os pressupostos da história da literatura, devemos investigar um livro pelos vieses que contemplem $\tilde{n}$ análise dos diversos autores (copistas, editores, livreiros, impressores, revisores, tipógrafos) e as diferentes operações que participam do processo de publicação dos textosò(CHARTIER, 2010, p. 38).

A partir desses gêneros literários populares ï romances para homens ï muito comuns nas prateleiras das livrarias, no comércio informal de livros e nos periódicos Oitocentistas (EL FAR, 2004), encontramos pistas que revelam as preferências do público leitor da época por determinadas leituras. Tais pistas vão desde os meios de impressão, circulação e o valor dos periódicos, até os modos de leitura dos sujeitos letrados do Brasil no fim do século XIX.

Essa prática de reconhecer a materialidade do texto e a prática de leitura durante uma investigação segue o que propõe Darnton (2010, p. 145): ñCom efeito, a tipografia, o estilo e a sintaxe determinam como os textos transmitem os sentidos.ò. Nesse sentido, acreditamos que considerar os estudos da materialidade do texto e o modo de apropriação do sentido realizado pelo leitor, nos permite compreender a posição assumida por Chartier no que diz respeito ao reconhecimento das várias modalidades de leitura de um dado povo:

Reconhecer-lhe as diversas modalidades, as múltiplas alterações, é o principal objectivo de um projecto de história da leitura, empenhado em apreender nas suas diferenças as comunidades de leitores e os seus modos de ler (CHARTIER, 1997, p. 6-7).

Seguindo essas ideias colocadas pela História Cultural, verificamos que uma justificativa possível para a repercussão que os ñomances para homensò tiveram na capital brasileira, Rio de Janeiro, corresponde à prática de leitura no mesmo período da história, ou 
seja, uma leitura solitária com intenções de atender aos desejos sexuais, diferente das práticas de leitura em público ou em voz alta, comuns ao contexto histórico da Idade Média até meados do século XVIII (CHARTIER, 2011).

Com a finalidade de respaldar teoricamente nossa pesquisa, elegemos alguns teóricos que assumem a história da leitura como um fazer científico a partir do entendimento de que o livro (e, por conseguinte, outros objetos, como o jornal) é um objeto cultural e, sob este prisma, a leitura é encarada como uma prática heteróclita que revela traços de uma determinada comunidade leitora, levando-se em consideração o tempo, o espaço, os meios de produção, de divulgação e de apropriação dos periódicos.

Primeiramente, de um modo geral para nossa investigação, elegemos as ideias de Chartier no que diz respeito ao tratamento que dá às práticas de leitura e as suas possibilidades de significação pela/na relação dialógica entre o texto e o leitor:

Reconstruir nas suas dimensões históricas este processo de ñactualizaçãoò dos textos exige, em primeiro lugar, considerar que os seus significados dependem das formas através das quais são aceites (sic) e adaptados pelos seus leitores (ou seus auditores) (CHARTIER, 1997, p. 14).

Para entendermos melhor essa significação do texto que é atribuída pelo leitor, pensamos no tratamento dado por Chartier (1997, p. 14) aos dispositivos de leitura aferidos pelo leitor: $\tilde{n}[. .$.$] é preciso considerar que as formas produzem sentido e que a um texto,$ estável na letra, é atribuído um significado e um estatuto inéditos quando se alteram os dispositivos que o propõem para a interpretaçãoò.

Nesse aspecto, para um tratamento detalhado do meio de circulação, produção e divulgação dos gêneros literários populares, em especial, os ñomances para homensò, recorreremos às ideias levantadas por El Far (2004), a qual nos dá todo o suporte necessário para discutirmos a apropriação do público Oitocentista que aderia à leitura pornográfica no Brasil:

Para melhor compreendermos o significado de uma novela, de um ñromance de sensaçãoò ou de um texto pornográfico temos, então, de levar em conta, além do conteúdo intrínseco dessas obras, seus mecanismos de confecção, distribuição e publicidade, que se encontram imersos em um contexto mais extenso de relações de natureza diversa (EL FAR, 2004, p. 76). 
Nessa mesma linha de raciocínio, da apropriação dos romances pornográficos pelos brasileiros do século XIX, analisaremos as questões trazidas por Del Priori (2011), que busca demonstrar a relação existente entre a apropriação da literatura pornográfica e o cenário da sexualidade no Brasil, desde a chegada da corte portuguesa no Brasil até o movimento higienista da medicina do século XIX:

Tempos de desejos contidos ou frustrados, o século XIX se abriu com as libertinagens de um jovem imperador e se fechou com o higienismo frio dos médicos. Século hipócrita que reprimiu o sexo, mas foi por ele obcecado. Que vigiava a nudez, mas olhava pelos buracos da fechadura. Que impunha regras ao casal, mas liberava os bordéis (DEL PRIORI, 2011, p. 100-101).

É nesse jogo fronteiriço entre as práticas de leitura e a representação da sociedade por meio da literatura que propomos uma investigação que contribua tanto para os estudos da História da Literatura como da História Cultural, uma vez que buscamos traçar o perfil da sociedade luso-brasileira no século XIX através do acesso aos romances pornográficos.

Vemos nessa relação entre o amor e a pornografia, presente nos gêneros literários populares do Brasil Oitocentista, a possibilidade de pensar questões sobre o sujeito leitor e suas práticas de leitura, que necessitam de uma contextualização física, espacial e temporal para poder fazer significar um texto.

Salientamos que para uma investigação que vê a realidade como forjada, ou representada, faz-se necessário recorrer aos postulados teóricos da História Cultural (como já dissemos). Considerar livros e jornais como bens culturais e tomá-los como objeto de estudo documental, observando como obras de ficção circularam em determinado período da história e como elas foram apropriadas pelos leitores, nos permite construir uma representação da sociedade e o discurso que circulava em Oitocentos, amparados na afirmação de Chartier: ñdaí a apropriação, por algumas ficções, das técnicas da prova próprias da história, a fim de produzir não ñfeitos de realidadeò, mas sim, preferencialmente, a ilusão de um discurso históricoò (CHARTIER, 2010, p. 28).

Tal afirmação de Chartier nos dá a pista de que os textos literários (ficcionais) que circularam em livros e jornais do século XIX no Brasil nos dão a ilusão de um discurso histórico que pode caracterizar as apropriações que foram feitas no Brasil dos romances pornográficos traduzidos da Europa e as efetuações, ou práticas, de leitura que marcam um 
período devotado à expurgação da sexualidade brasileira, em especial a que não tinha fins religiosos (para procriação).

\section{Um breve panorama do jornal $O$ Riso: a pornografia ao custo de um jornal}

Por limitações da natureza desse artigo, ${ }^{2}$ realizaremos nessa seção uma visão geral do jornal $O$ Riso e algumas considerações acerca dos conceitos de representação, práticas e apropriação.

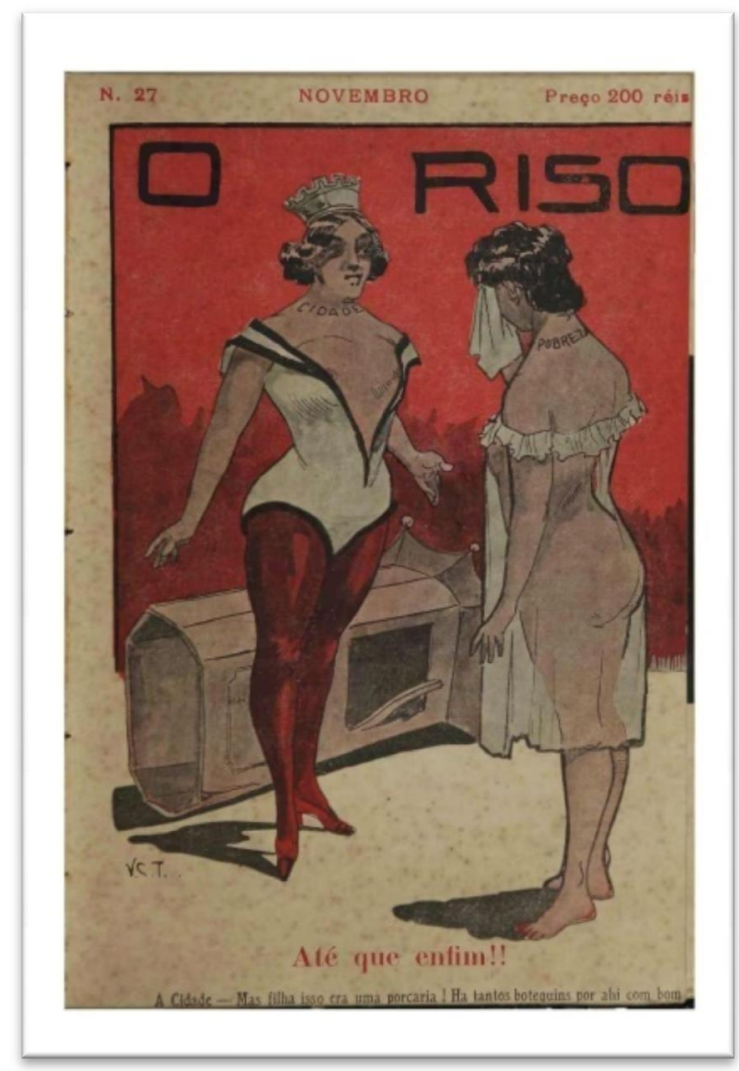

Figura 1: Capa de $O$ Riso, n. 27

Fonte: $O$ Riso, Rio de Janeiro, 23/11/1911, Num. 27, Anno I, Capa.

O jornal $O$ Riso teve seu primeiro número circulando no Estado do Rio de Janeiro em 26 de maio de 1911 com a tipografia instalada na Rua da Alfandega, n. 182. Teve como proprietário o impressor Rebello Braga, que assumiu o jornal até a publicação de número 46, ano II, no dia 04 de abril de 1912. A partir do número seguinte, ou seja, 47, ano II, com saída em 11 de abril de 1912, o jornal teve a sua frente os proprietários A. Reis \& C. Rebello Braga

\footnotetext{
${ }^{2}$ Para uma visão mais ampla acerca da circulação da imprensa pornográfica no Brasil, conferir Azevedo \& Ferreira Júnior (2017). Essa pesquisa foi desenvolvida com a versão impressa, mas o jornal também está disponível no site da Biblioteca Brasiliana Guita e José Mindlin.
} 
que já tinha experiência com jornais pornográficos. O jornal $O$ Coió circulou por dois anos, 1901-1902, na cidade do Rio de Janeiro, com publicação de oito páginas que eram vendidas duas vezes na semana, ao custo de 100 réis, com sede na Rua do Ouvidor, n 44 . Não havia referência ao proprietário no primeiro ano de circulação, mas a partir do número 61, assina a propriedade e a direção do jornal Rebello Braga, que, como já mencionamos, foi proprietário de $O$ Riso.

No número de comemoração de 1 ano do jornal, os novos proprietários dedicam uma seção ao seu antigo responsável:

O Braga

Ahi têm os leitores a carantonha ${ }^{3}$, perdão! a carinha do papá dôO Riso, pois foi elle quem deu á luz $̈$ salvo seja! ï esse travesso petiz que hoje colhe a primeira flor no jardim de sua preciosa... etc. etc. e isso graças á boa qualidade da semente plantada, que, germinou lindamente, para Gaudio dos leitores e delicia das leitoras...

Ao Braga, pois, abraçamos effusivamente pela festiva data, na qualidade de preceptores que somos do endiabrado pequeno, cujos direitos paternaes nos passou (O Riso, 53, ano II, p. 4).

Mesmo tendo sido administrado por proprietários em épocas diferentes, o jornal $O$ Riso teve como principal seção literária os romances folhetins, nomeado por seus proprietários de romance jovial, ñAs Aventuras do Rei Pausoloò e ñSupremo Abraço: romance dâmorò, por Victorien du Saussay, que traziam em sua composição elementos característicos dos romances para homens, tais como: temática sexual servindo de pano de fundo na narrativa; descrição de cenas de sexo; apologia as práticas sexuais (heterossexuais e homossexuais); entre outros. Destacamos que expressões como ñomances para serem lidos com uma mãoò, ñromances joviaisò, ñomances para homensò e ñiteratura alegreò eram comumente utilizadas para divulgação de livros, álbum de fotografias e romances folhetins com a temática pornográfica. Era por meio das referidas expressões que o leitor identificava um tipo específico de literatura: romances, poesias e arte pornográfica.

O jornal tinha uma média de 16 páginas por exemplar (podendo chegar em alguns números ao total de 22 páginas), dividido em duas colunas, com uma tiragem de 15.000 exemplares (constando o número da tiragem a partir do número 4, de 15 de junho de 1911) ao custo de 200 réis por edições avulsas do primeiro ao último número no ano de 2012. A

\footnotetext{
${ }^{3}$ Há uma caricatura de Rebello Braga ao lado da nota. 
tiragem aumenta para o quantitativo de 19.000 exemplares a partir do n. 60, de 11 de julho de 1912, já com a nova administração.

A tentativa de controle de leitura imposta pelo editor de $O$ Riso, Rebello Braga, é na verdade uma invenção, uma construção forjada. Ao caracterizar o jornal como sendo voltado para ñcousas inuteis, do supérfluoò e preocupado com ñesthetica e bom humorò, o editor induz o leitor a guiar a leitura do jornal pelo tom do desprendimento, mas ao mesmo tempo o impresso traz críticas duras ao governo vigente, a presidência de Hermes da Fonseca. Seja por meio da polícia, dos militares, ou dos ministros e secretários do governo, as páginas de $O$ Riso estão cheias de denúncias políticas e sociais, mas sempre associando o conteúdo ñsérioò ao humor e ao erotismo.

O que acontecia em $O$ Riso era uma estratégia editorial dos proprietários de jornais pornográficos e humorísticos $\ddot{i}$ tomamos como conceituação de estratégia a definição de ñcálculo (ou a manipulação)ò (CERTEAU, 2012, p. 93) ï, que apresentava logo na capa do impresso o discurso do humor e da pornografia como forma de atrair o leitor. Vale destacar que, assim como Michel de Certeau observou nas práticas de consumo cultural, o par dicotômico estratégia/tática, no que diz respeito à leitura, tem uma relação intrínseca com a questão do poder. Nesse sentido, estratégia e tática representam os movimentos de poder e submissão da sociedade, respectivamente.

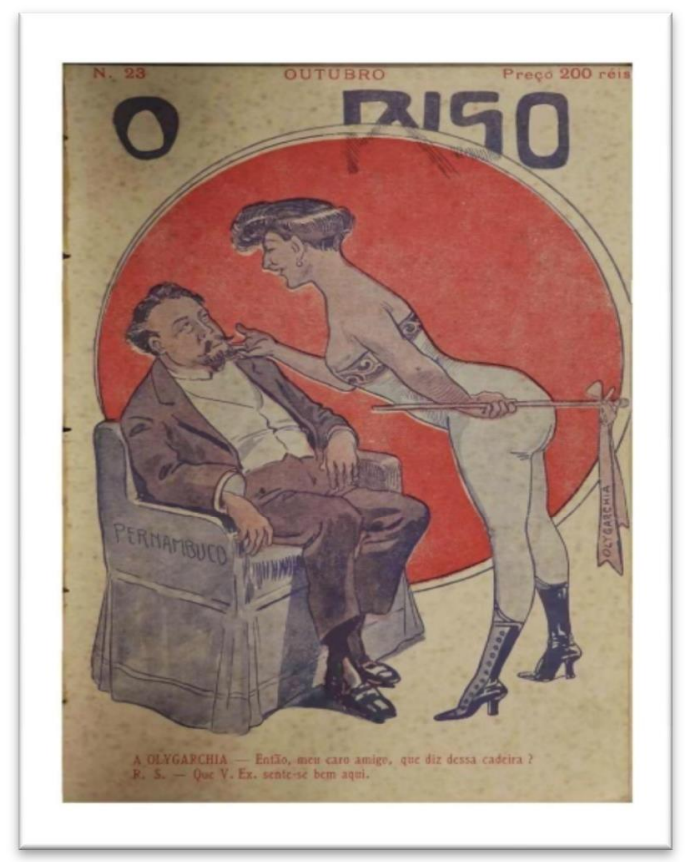

Figura 2: Capa de $O$ Riso, n. 23

Fonte: $O$ Riso, Rio de Janeiro, 26/10/1911, n. 23, ano I, Capa). 


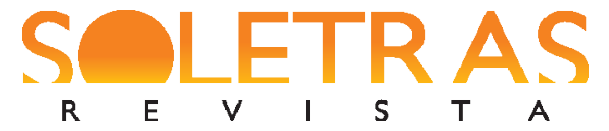

A partir do número 17 (até o 19), o proprietário do jornal, Rebello Braga, aposta no humor, com gravuras que exploram o sexo, mantendo a estratégia de atrair o leitor que busca o conteúdo pornográfico no jornal.Com a publicação do número 20 (até o 32), Rebello Braga investe na sátira política, por meio de gravuras que abordam crises políticas e/ou sociais, a partir de outubro de 1911. Esse período é marcado pela disputa do governo de Pernambuco (Cf. Figura 2) entre Dantas Barreto, apoiado pelo Marechal Hermes da Fonseca, e Rosa e Silva, representante da oligarquia ñosistaò pernambucana. O apoio do Marechal a outros militares era sempre mencionado e criticado pelo jornal $O$ Riso.

A temática sexual está presente em todas as capas de todos os números do jornal $O$ Riso com a impressão de fotografias de nu artístico. Outras fotografias do mesmo gênero preenchem outras páginas dentro do jornal.

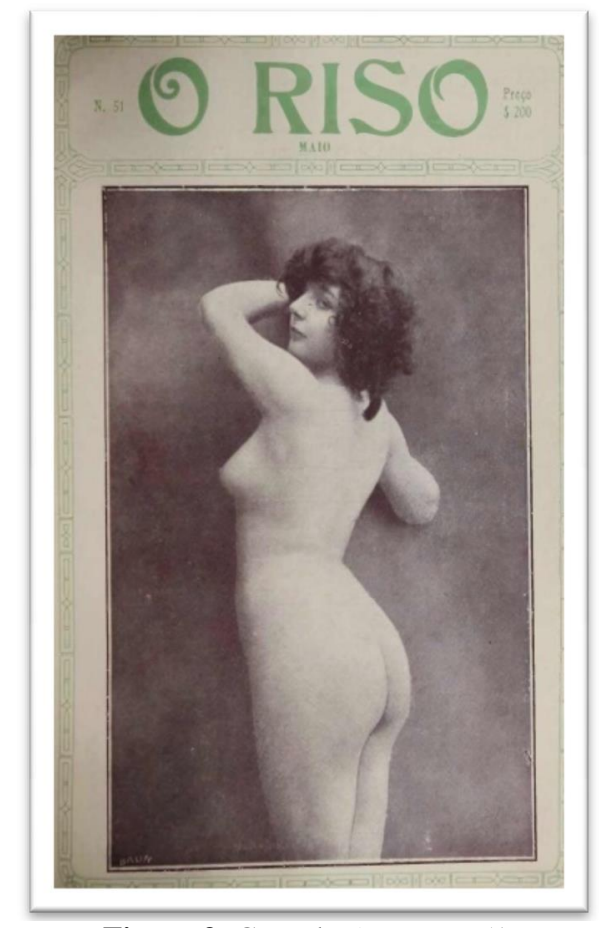

Figura 3: Capa de $O$ Riso, n. 5

Fonte: $O$ Riso, Rio de Janeiro, 09/05/1912, n. 51, ano II, capa.

Além das fotografias, $O$ Riso é composto por outros gêneros literários como crônicas, romances rápidos, contos, poemas, sonetos, cartas, charges, caricaturas, anedotas e piadas. Nem todos os gêneros em questão trazem em seu cerne a temática sexual, porém vemos que principalmente nas imagens o ñduplo sentidoòé explorado. 
As noções de representação, práticas e apropriação que se encontram em meu livro de 1988 propunham uma aproximação que insistia mais nos usos particulares do que nas distribuições estatísticas. Nesse sentido, chamava a atenção para os gestos e comportamentos, e não apenas para as ideias e os discursos, e considerava as representações (individuais ou coletivas, puramente mentais, textuais ou iconográficas) não como simples reflexos verdadeiros que vão construindo as próprias divisões do mundo social (CHARTIER, 2010, p. 7).

Vemos nas palavras de Chartier o mote para entendermos que as pistas para apreendermos as noções de representação, práticas e apropriação de que a sociedade lusobrasileira Oitocentista vivenciou não depende exclusivamente dos discursos ficcionais (os romances pornográficos), mas de todo o tratamento dado aos jornais específicos da época e dos outros gêneros literários que compunham o jornal $O$ Riso.

\section{Rabelais e o sucesso pornográfico: A História de Cada Uma}

No mesmo período de fim do século XIX, circulou ñum álássicoô do gênero [romances para homens] ò(EL FAR, 2004, p. 15), o romance pornográfico A História de Cada Uma: serões do convento ( $\mathrm{s} / \mathrm{d})$, assinada pelo pseudônimo de Rabelais, que narra as experiências sexuais de freiras, contadas pelas próprias personagens. Rabelais foi um dos pseudônimos mais usados por Alfredo Gallis (1859-1910) no final de século XIX. O autor era muito consumido pelos leitores Oitocentistas, tanto no gênero naturalista como na literatura pornográfica (MENDES, 2016):

O mais prolífero de todos os autores dessa época foi um tal «Rabelais», vulgarmente confundido, nos catálogos das bibliotecas, com o reputado escritor francês do século XVI. Não se trata, porém, da recuperação de obras esquecidas de François Rabelais Chinon. Estamos perante um português que usou aquele pseudónimo três séculos depois. Trata-se de Joaquim Alfredo Gallis, o autor que mais popularidade granjeou na transição da centúria de oitocentos para a seguinte, com uma larga projecção no Brasil. Gallis nasceu em Lisboa em 1859 e morreu a 24 de Novembro de 1910. Foi administrador do concelho do Barreiro desde 1 de Fevereiro de 1901, lugar que ocupou até 1905, embora com uma escassa presença física naquela localidade, preferindo delegar no seu secretário (VENTURA, 2011, p. 168).

Trazemos para esse espaço uma explanação de ñRabelaisò para exemplificar o tipo de literatura pornográfica que circulava no fim do século XIX e início do XX, em meio à clandestinidade e ao anonimato, pois ñpara os autores, a clandestinidade supõe naturalmente o anonimato, ou o recurso a pseudônimosò (MAINGUENEAU, 2010, p. 93). 
A narrativa inicia com a abadessa e noviças rememorando os atos sexuais e se permitindo ao gozo. A história se passa na véspera do dia de São João com as freiras reunidas na casa do recreio para contar as suas aventuras sexuais:

Como sabeis, cada uma de nós vai contar a primeira aventura galante da sua existência, aquela que deu pelo menos quebra ao cabaço, porque, como deveis concordar, o signo de Virgo é coisa que não existe no nosso sistema conventual (RABELAIS, s/d, p. 4).

O romance é dividido em 11 capítulos, a saber: ño passado de uma abadessaò, ñUma freira modeloò, ñHistória da Clarinha: ao que leva à curiosidadeò, ñHistória de D. Violante: guardar uma mulherò, ñHistória de D. Margarida: quadros realistas contra a virtudeò, ñHistória de D. Angélica: o que uma menina viu e fez... até os 15 anosò, ñHistória de D. Guilhermina: ver é bom, gosar é melhorò, ñHistória de D. Virginia: quadros defesosò, ñHistória de D. Cecília: a mocidade de uma noviçaò, ñHistória de D. Delfina: virgem!ò e, por fim, o último capítulo: ñConhecimentos antigosò. Este último se divide em 4 partes que caminham para o arremate da narrativa, findando o dia de véspera de São João após as mais voluptuosas histórias narradas, culminando em um apogeu do desejo.

Na primeira parte, ñConhecimentos antigosò, D. Margarida ao sair do convento e se aproximar da cerca que dá acesso ao recinto ñna manhã de 23 de junho de 18...ò(RABELAIS, s/d, s/p) se depara com o novo hortelão que estar a cuidar dos craveiros. A freira empolga-se com o robusto homem e é revelado ao leitor que se trata de Manoel, seu antigo amante e pai de sua filha. Ao final do encontro, eles marcam às onze da noite para conversarem e se entregarem aos prazeres acumulados.

Na segunda parte, ñO novo capelãoò, chega ao convento um jovem e belo padre que aguça os mais luxuriosos desejos das freiras, em especial D. Margarida, que toma para si a missão de seduzir o capelão.

Na terceira parte, r̃Entre noviçasò, as religiosas se queixam que estão há tempos satisfazendo-se umas com as outras, fazendo as vezes do homem. Cogitam então seduzir o capelão e o hortelão. De imediato, D. Margarida tenta subverter esse plano, alegando que mais cedo tentara seduzir o hortelão, mas não conseguira êxito. Apesar da tentativa de despistar as irmãs em relação à sedução do hortelão, as religiosas tomadas de desejos luxuriosos armam um plano para arrebatar Manoel, o hortelão, e padre Francisco, o novo capelão. 


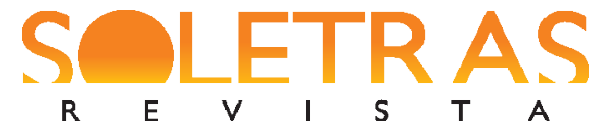

Na quarta e última parte, ñÀs onze da noiteò, D. Margarida, disposta a não dividir o cetro de seu amado com as outras freiras, decide contar-lhe os planos de sedução de D. Delfina. Após fecharem a porta da cela de D. Margarida, entregam-se às mais lúbricas ações de gozo até o cair da madrugada. A narrativa encerra com a descrição da cópula e do tesão acumulado de três anos entre Manoel e D. Margarida.

Vale salientar que, apesar da ampla circulação e produção de material impresso pornográfico (a exemplo das obras de ñRabelaisò) com textos, fotografias, charges e publicidade erótica como vimos nessa ñinfluênciaò nos impressos de Oitocentos, a prática de produção de materiais pornográficos não era vista com r̃̃ons olhosò pela sociedade da época.

O período de circulação de tal literatura, final de século XIX e início do XX, foi marcado pela censura policial, médica e religiosa em torno da discussão acerca da sexualidade. Segundo El Far (2007. p. 289), ño Código Penal Republicano (1891), por sua vez, não fazia menção explícita à produção e disseminação de obras pornográficas, limitandose, de modo genérico, a punir possíveis atentados ao pudor e ofensas públicasò. Nesse sentido, percebemos que não havia uma lei explícita que punisse os responsáveis pela circulação de material pornográfico e os compradores de material ñproibidoò, mas a censura pelo viés da moralidade era frequente, pois a influência do catolicismo português ainda era muito forte no Brasil, fato esse que marca o século XIX como o período mais ñhipócritaò da história brasileira (Cf. DEL PRIORI, 2011).

Em uma seção intitulada ñContra a Pornographiaò, publicada no jornal Gazeta de Notícias, de 07 de fevereiro de 1911, encontramos a publicação do seguinte manifesto conservador:

Por falta de espaço deixámos hontem de publicar uma representação do Circulo Catholico contra a exibição e publicação de cousas pornográficas nessa capital. [...]

Eis a representação:

Exmo. Sr. presidente da Republica dos Estados Unidos do Brasil. Á presença de V. Ex. vêm os cidadãos infra-assignados, membros de várias associações catholicas estabelecidas nesta capital a que a convite do Circulo Catholico do Rio de Janeiro a elle se reunem para o exercício do direito da representação, assegurado pela Constituição vigente, em seu art. $72 \S 9^{\circ}$. O que nos induz, a nós os signatarios desta representação, não é o interesse de nossa opinião religiosa; não se trata agora de reinvindicações de algum de nossos direitos acaso postergados, nem tampouco impetramos favores para a nossa confissão, propugnamos apenas, Exmo. Sr. ï e fazendo-o cumprimos religioso dever $\ddot{i}$ a causa da moral e do pudor publico liames estes que mais fortemente robustecem as nações e sem os quais inevitável se torna o seu 
desmembramento e ruína. É de pública notoriedade, Exmo. Sr. o incremento que entre nós e nesta cidade vão tomando as exhibições theatraes e outras congeneres, e bem assim a imprensa despejadamente licenciosa quer no livro, quer ainda com maior perigo em samanarios e jornaes. Tudo quanto a lascivia e o impudor podem cogitar de mais deslavado e cynico quotidianamente as exhibições em folhas apregoadas e vendidas sob as vistas das auctoridade, em peças immoralíssimas, que com toda razão têm sido proscriptas dos theatros em paizes zelosos dos seus bons costumes, e ainda em fitas cienmatographicas, que com viva realidade deparam sensualíssimas torpezas (Gazeta de Notícias, Rio de Janeiro, Anno XXXVI, n. 38 , em 07/02/1910, p. 4).

Essa publicação na Gazeta de Notícias acerca do ñncômodoò que peças, livros e jornais pornográficos causavam aos representantes da comunidade católica de início do século XX permite compreendermos a representação da pornografia pela ótica da sociedade conservadora.

A solicitação dirigida ao então Presidente da República, Hermes da Fonseca, reivindicava o cumprimento da lei, em relação à devida punição para os crimes que atentam contra a moral e o pudor, além de denunciar o descaso das autoridades que tinham conhecimento de tais produtos considerados lascivos e não faziam cumprir a lei. Inclusive, na solicitação da Comunidade Católica, os assinantes do abaixo-assinado lembram que p̃países zelosos de seus bons costumesò proibiram e/ou condenaram as ações criminosas de disseminação de obras pornográficas e assim deveria ser feito no Brasil.

Por mais que não houvesse uma punição legal (EL FAR, 2007), a leitura de livros e jornais pornográficos era vista de forma enviesada pela sociedade de transição de século XIXï XX. As ñgrandes vítimasò dessa comunidade leitora foram as mulheres, seja por sua exclusão do mercado editorial pornográfico $i ̈$ os gêneros literários pornográficos eram explicitamente voltados para os homens (ñeitura só para homensò, ñomance para homensò, ñeitura para homensò, ñcontos para velhosò eram expressões comumente usadas para se referir aos textos pornográficos) $\ddot{i}$, seja pela ñfragilidade mentalò que era atribuída às mulheres pelos médicos e religiosos de oitocentos.

Como o próprio termo sugere, os enredos que recebiam tal subtítulo deveriam ser proibidos às mulheres, vistas naquela época como pessoas de personalidade frágil, por isso, suscetíveis aos encantos da narrativa. Entregues a essas histórias, as leitoras poderiam se esquecer das convenções sociais e sair em busca de emoções e afetividades distantes de sua realidade. Os homens, de modo diferente, por serem capazes de discernir o mundo da ficção do cotidiano das regras e dos bons costumes, não corriam o mesmo 


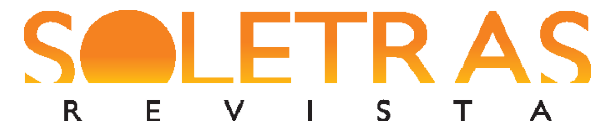

risco. Por isso, tinham acesso irrestrito a essas leituras (EL FAR, 2007, p. 290).

Porém, vale lembrar que essa afirmação é sobre os títulos das obras pornográficas, pois, como bem observou Michel de Certeau (2012), o leitor é dotado de astúcias para desviar e subverter as normas sociais em nome da prática de leitura. Mas as mulheres não eram as únicas reprimidas em relação à leitura de romances pornográficos.

Os homens, por sua vez, deveriam evitar o estilo de vida celibatário, quer dizer, o cotidiano de bailes, festas e de namoros efêmeros. Esse tipo de comportamento não representava apenas uma recusa aos ideais do casamento e da família, como provocava também o crescimento de casos de aborto, infanticídio, prostituição e de doenças sexualmente transmissíveis. Nessa perspectiva médica, o corpo sofria inevitavelmente uma enorme debilidade, tornando-se fraco, impotente e ñgastoò A disseminação dessas idéias no final de oitocentos era tão eficaz que o romance intitulado Um homem gasto (1885), assinado pelo pseudônimo L. L., rapidamente ganhou espaço nas colunas da crítica literária daquele período. Tratava-se do drama de um rico brasileiro, recém-casado, que, em resposta aos anos de libertinagem, via-se impedido de consumar seu casamento. Nas palavras publicadas num jornal, faltava-lhe o ñessencial para as funções matrimoniaisò (A Semana, 9/5/1885). Desesperado, o protagonista, ñjá gastoò, procurava a ajuda dos médicos para remediar sua situação. Depois de provar em vão reagentes e medicamentos, o herói enlouquecia e, em seguida, cometia o suicídio (L.L., 1885). Além de possuir cenas provocativas, Um homem gasto, anunciado como um ñromance para homemò, assim como Amar, gozar e morrer..., parecia acreditar nos preceitos científicos propagados na época (EL FAR, 2007, p. 301).

Aos homens restavam as punições físicas. Segundo as pesquisas médicas de fim de século XIX (EL FAR, 2007), os homens que liam romances ñproibidosò poderiam desenvolver algum mal na saúde, como: doenças sexualmente transmissíveis (a divulgação de produtos para cura da sífilis e da gonorreia eram frequentes nos jornais Oitocentistas), debilidade mental, desgaste físico, anemia, entre outras.

\section{Laurindo Rebello: uma história pelo buraco da fechadura}

A título de apagamento da literatura pornográfica, gostaríamos de exemplificar com uma publicação de livro de poesias que antecedia a produção de nossos jornais em um curto tempo de menos de uma década.

Quase no mesmo período em que circulou o jornal $O$ Rio $N u(1898-1916)$ e as obras de ñRabelaisò dominavam o cenário livreiro pornográfico, foi publicado no Brasil um livro de 
poesias, intitulado Obras Poéticas Livres (1882), que explorava as mesmas temáticas da sedução, fornicação, prostituição, defloramento de jovens, entre outros, por Laurindo José da Silva Rebello.

Segundo Fábio Frohwein de Salles Moniz (2012), a biografia de Laurindo é permeada por controvérsias, uma vez que não há unanimidade pelos estudiosos da história da literatura e pelos críticos literários acerca da grafia correta do nome de Laurindo como também sobre as datas de suas publicações. Moniz (2012) afirma que a única obra publicada em vida foi Trovas (1853). Os outros livros foram organizados a partir de poemas, lunduns e modinhas espalhadas nos periódicos do Oitocentos, a exemplo da Marmota Fluminense (1857). Ainda segundo Moniz (2012), Laurindo faleceu em 28 de setembro de 1864, ou seja, dezoito anos antes da publicação póstuma de seu livro de poemas pornográficos.

O editor (ou editores) da obra erótica póstuma optou por organizar o livro dividido em grupos nomeados ñMotteò, ñDecimaò, ñSatyraò, ñSonetoò, ñDialogoò e ñLundúò. Percebemos uma predileção na edição da obra pela publicação de motes (30 ao todo), mas, selecionamos para analisar em nosso artigo, a publicação das Décimas. Destacamos que a ñDécimaò é uma arte poética construída por uma estrofe ou poema, contendo dez versos, ñvastamente empregada, sobretudo como estrofe, nos século XVII e XVIIIò(MOISÉS, 1985, p. 137).

\author{
OUTRA \\ Assim como um galho é rama \\ Eôuma vara cipó, \\ Também póde ser Socó \\ Quem Feliz-asno se chama: \\ Um leito também é cama, \\ Uns dizem gesso, outros giz; \\ Um grande beque é nariz, \\ De um botão brota uma flôr; \\ Mas um burro senador! \\ De certo é asno feliz! (REBELLO, 1882, p. 26).
}

A Décima acima nos dá a pista de que a crítica política também se fazia presente nos poemas de Rebello. A galhofa com envergadura erótica serve de instrumento satírico para o rebaixamento político (ñ̃urro senadorò / ñasno felizò), caracterizando um dos ñugaresò que a pornografia assume na literatura: a crítica política como também observamos no jornal $O$ Riso. Essa apropriação da pornografia como instrumento de crítica e a utilização da sátira como recurso artístico a serviço das técnicas do maldizer, provoca o riso e o escárnio, mas excita o leitor ao mesmo tempo. A excitação surge como pano de fundo, uma vez que ñ [...] a 
pornografia não é o ponto principal das referências sexuais na sátiraò (HODGART, 2010, p. $28)^{4}$

$\mathrm{Na}$ Décima abaixo, vemos outra apropriação da pornografia na literatura e como esta representa a relação sexual vista pela ótica da culpa (ñnCom seu rebolar malino / Poz-me a mente tão corruptaò). Para comunidade católica do Oitocentos, como vimos anteriormente na seção ñContra a Pornographiaò, publicada no jornal Gazeta de Notícias, a relação sexual que não fosse para fins da procriação era vista sob a ótica do pecado e, por conseguinte, do crime, merecendo ser objeto de controle e punição (Cf. FOUCAULT, 1984a; 1984b; 2013).

\section{DECIMA}

Certa mulher de um marquez

Fodi por cousa nenhuma,

Mas fodi sómente uma,

Deus me livre de outra vez!

A tal putinha me fez

Na porra ${ }^{5}$ tal desatino,

Com seu rebolar malino

Poz-me a mente tão corrupta

Que julguei no cú da puta

Encontrar o palatino! (REBELLO, 1882, p. 10)

Nessas últimas Décimas que apresentaremos, encontramos a presença da sátira sem intenções políticas. É bem verdade que elementos distintos como a crítica, a chantagem, o desejo, a paixão e a política compõem-se como temas para sátira, fato este que nos leva a concordar com Hodgart (2010) de que mais que um gênero, a sátira é um movimento de linguagem que faz parte da condição humana, no que diz respeito ao ataque a outrem. Esse ataque pode ser tomado pela representação de um ato de ciúme ou queixa por não ter sido o único pretendente da mulher desejada.

\section{DECIMA}

Por aqui uma só vez

Não passo por esta rua,

Que não veja esta perua,

Na porta com dous ou tres;

Que fodas não dá no mez

Aquelle cono tão quente!

E chega a ser tão potente

\footnotetext{
${ }^{4} \tilde{n}[\ldots]$ the pornography is not the main point of the sexual references in satireò. Tradução nossa.

${ }^{5}$ De acordo com o Dicionário de termos eróticos e afins, organizado por Horácio de Almeida (1981), o significado de ñporraò pode ser o membro viril (pênis ereto) ou o esperma. No contexto do poema de Rebello, o significado que melhor se enquadra é o primeiro, pênis ereto.
} 
A maldicta da cachorra,

Que no cú sempre tem porra,

Na porta sempre tem gente! (REBELLO, 1882, p. 45)

\section{DECIMA}

No A B C de Cupido

Errou você desta vez,

Porquanto com um $\mathrm{C}$ fez

Perder de somno o sentido.

Somno com C só ouvido

Enteza a porra a seu dono;

Com C não se escreve somno,

Aprenda com mais trabalho:

Com C se escreve caralho

Com que vi foder seu cono! (REBELLO, 1882, p. 52).

No primeiro exemplo, encontramos versos como ñQue não veja esta perua, / Na porta com dous ou tresò que demonstram a insatisfação de ver a mulher deseja cedendo aos desejos sexuais com outros homens, seguido do achincalhamento motivado pela paixão: ñA maldicta da cachorra, / Que no cú sempre tem porra, / Na porta sempre tem genteò.

$\mathrm{Na}$ última Décima, temos um caso bem particular de uma representação autobiográfica, conforme a nota acima, dos desejos sexuais de Rebello Braga.

Esta decima foi feita a uma moça que marcára uma entrevista ao poeta. Tendo-se este demorado, recebeu ella um outro amante; o poeta chegou mais tarde e pelo buraco da rotula vio uma scena sobre o sofá, por demais erotica, pelo que retirou-se sem entrar. No outro dia ella escreveu-lhe, dizendo-lhe que por sua causa perdera o $\ddot{i}$ o cono $\ddot{i}$ toda a noite; a resposta foi essa decima (REBELLO, 1882, p. 52, nota do editor).

O eu lírico evoca Cupido, deus do amor, demonstrando a subversão da apropriação do amor pelos versos ñNo A B C de Cupido / Errou você desta vez,ò. Em seguida, após chegar atrasado ao encontro amoroso e espreitar a mulher em uma relação sexual com outro homem, o eu lírico constrói a representação do ataque de paixão (um dos elementos da sátira) devido aos seus ciúmes por ter sido trocado pela mulher desejada: ñCom $\mathrm{C}$ se escreve caralho / Com que vi foder seu cono! ’̀.

A presença de Laurindo Rebello em nosso artigo se justifica por sua obra de poemas eróticos, uma vez que a historiografia da literatura faz menção ao poeta sempre associada as suas trovas, modinhas e suas publicações na Marmota Fluminense (1857), segundo Moniz (2012), além do destaque (e reconhecimento) que o autor teve na Academia Brasileira de 
Letras (ABL). Vale destacar que o referido poeta foi Patrono da Cadeira 26 da ABL e mesmo assim a sua obra pornográfica caiu no esquecimento.

Para produção de suas poesias pornográficas, Rebello não utilizou nenhum pseudônimo, como era comum à época (ñRabelaisò é um grande exemplo dessa prática), mesmo em se tratando de literatura pornográfica. De acordo com Barbosa (2007, p. 32), em seus estudos sobre a história da literatura e da leitura nos jornais Oitocentistas lusobrasileiros, ñobserva-se uma tendência forte ao anonimatoò mas essa configuração de autores/editores anônimos e/ou a utilização de pseudônimos vem de além-mar. Assim como acontecia nas publicações brasileiras (que tendiam a imitar os jornais europeus, em especial, ingleses e franceses), os editores da Europa utilizavam este recurso do anonimato/pseudônimo para se prevenir das punições legais ou por não ter importância o nome do autor, ñtalvez porque a prevalência seja a da palavra escrita e não daquele que escreveò (BARBOSA, 2007, p. 35).

\section{Algumas considerações finais}

Para traçarmos um perfil da literatura pornográfica brasileira que circulou em impressos de final do Oitocentos, precisamos recorrer a um contexto ocidental mais amplo que trate de jornais e livros pornográficos europeus, uma vez que há uma clara influência destes na composição dos impressos brasileiros. Sendo assim, trabalhamos com duas obras acadêmicas que se propuseram a construir a história da pornografia na literatura ocidental e uma possibilidade de análise de obras pornográficas. Porém, gostaríamos de ressaltar que tanto Alexandrian (1993) como Hunt (1999) dedicaram seus estudos apenas ao contexto europeu, principalmente à literatura francesa e à inglesa, consideradas pelos estudiosos como o berço da literatura pornográfica.

A partir desses pressupostos, a fim de restaurar o apagamento da literatura pornográfica brasileira, causada pelo hiato deixado pelos historiadores da imprensa e da literatura, propomo-nos a construir uma breve história da literatura erótica dos trópicos pelo buraco da fechadura dos livros e impressos do fim de século XIX.

Interessou-nos nessa construção da história resgatar os sentidos dos termos utilizados para os romances pornográficos, além de indicarmos alguns livros do gênero, que circularam no Brasil de fim do século XIX e início do XX. 


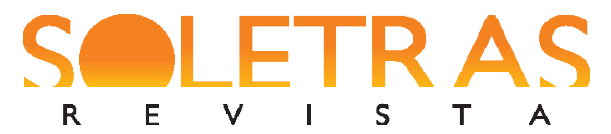

Dessa forma, trazer à cena a literatura pornográfica que circulou no jornal $O$ Riso, a arte pornográfica no livro de Rabelais e o resgate do patrono da Academia Brasileira de Letras, Laurindo José da Silva Rebello, com seus poemas eróticos, auxiliam na construção de uma representação da história da literatura luso-brasileira que tanto circulou nos séculos XIX e XX no Brasil.

Nesse aspecto, a pornografia deve ser vista na singularidade de sua produção de sentido, pois não há uma homogeneidade em sua composição. Com base nessa constatação, fica patente também que a pornografia cria distintos modos de produção de sentido, pois a cada situação posta nos livros e nos jornais, é necessário compreendermos qual o significado da pornografia naquele discurso. Por isso, é mister nos envolver com o discurso da época em que os livros e os jornais foram produzidos e circularam. As pistas da produção de sentido só aparecerão a partir do momento que reconhecermos a história e o discurso de sua época.

Por ora, acreditamos que um estudo historiográfico da literatura não deve ficar restrito aos textos consagrados pela história e pelas instâncias de consagração, menos ainda a figura de um autor que por questões particulares se destacou no cenário livreiro. Interessou-nos, portanto, verificar essa multiplicidade de vozes que ecoam na leitura de um romance, em especial o pornográfico, ou seja, ña análise dos diversos autores (copistas, editores, livreiros, impressores, revisores, tipógrafos) e as diferentes operações que participam do processo de publicação dos textosò (CHARTIER, 2010, p. 38). Afinal, uma leitura que busca explorar os desejos mais íntimos de uma sociedade que convivia de forma paradoxal com o sexo revela uma prática de leitura muito singular: ñuma leitura que mobiliza o corpo e os sentidosò (CHARTIER, 2007, p. 39).

Assim, nossa pesquisa pode contribuir com ñoutros modos de ler e de fazer circular a literatura e a culturaò (BARBOSA, 2007, p. 24), além de trabalhar em prol do preenchimento da lacuna de uma historiografia da literatura mais ampla, como destaca Zilberman (2003, s/p): ñAinda não foi completada a história que narra a dívida da literatura brasileira para com o jornalismo, especialmente no século 19.ò.

Nesse sentido, observamos que tratar da história da literatura não se restringe apenas à circulação de livros e de autores que de alguma forma foram ñescolhidosò pelas instâncias de consagração e passaram a figurar no rol do cânone literário de Oitocentos. Percebemos que ao investigar obras impressas (livros e jornais) e autores preteridos pela historiografia da 
literatura, contribuímos com as discussões acerca das práticas de leitura e da representação da comunidade leitora dos Oitocentos.

Por fim, observamos em nossa pesquisa que os impressos e autores considerados ñmoraisò eram vastamente consumidos no fim de século XIX e início de século XX, mas de algum modo foram deixados à margem das pesquisas acadêmicas e das reedições no mercado livreiro. Desse modo, (re)construir esse cenário libidinoso da literatura luso-brasileira pelo ñburaco da fechaduraò da historiografia da literatura se mostra como um manifesto em defesa da arte erótica e da ampliação dos estudos da história da literatura.

\section{Referências}

ALEXANDRIAN, (Sarane). História da literatura erótica. 2. ed. Trad. Ana Maria Scherer e José Laurênio de Mello. Rio de Janeiro: Rocco, 1993.

ALMEIDA, Horácio de. Dicionário de termos eróticos e afins. 2. ed. Rio de Janeiro: Civilização Brasileira, 1981.

AZEVEDO, Natanael Duarte de; FERREIRA JÚNIOR, José Temístocles. Trajetórias pornográficas: a literatura luso-brasileira por meio de livros e jornais. Raído, Dourados, MS, v. 11, n. 26, jan./jun. 2017, p. 127-145.

BARBOSA, Socorro de Fátima Pacífico. Literatura e periódicos no século XIX: perspectivas históricas e teóricas. Porto Alegre: Nova Prova, 2007.

BOURDIEU, Pierre. A economia das trocas simbólicas. 6. ed. São Paulo: Perspectiva, 2005. (Coleção estudos: 20).

CERTEAU, Michel de. A escrita da história. 2. ed Rio de Janeiro: Forense Universitária, 2006.

. A invenção do cotidiano. Artes de fazer. 19. ed. Trad. Ephraim Ferreira Alves. Petrópolis, RJ: Vozes, 2012.

CHARTIER, Roger. O mundo como representação. In: Estudos Avançados, 11(5), 1991, p. 173- 191.

A ordem dos livros. Trad. Leonor Graça. Lisboa: Vega, 1997.

. Leituras e leitores na França do Antigo Regime. Trad. Álvaro Lorencine. São Paulo: Editora UNESP, 2004.

. Inscrever e apagar: cultura escrita e literatura. Trad. Luzmara Curcino Ferreira. São Paulo: Editora UNESP, 2007.

. A história ou a leitura do tempo. Trad. Cristina Antunes. 2. ed. Belo Horizonte: Autêntica Editora, 2010.

Práticas da leitura. Trad. Cristiane Nascimento. 5. ed. São Paulo: Estação Liberdade, 2011. 
COSTA, Carlos. A revista no Brasil do século XIX: a história da formação das publicações, do leitor e da identidade do brasileiro. São Paulo: Alameda, 2012.

DARNTON, Robert. $O$ beijo de Lamourette: mídia, cultura e revolução. Trad. Denise Bottmann. São Paulo: Companhia das Letras, 2010.

DEL Priori, Mary. História do amor no Brasil. São Paulo: Contexto, 2005.

Histórias íntimas: sexualidade e erotismo na história do Brasil. São Paulo: Editora Planeta do Brasil, 2011.

EL FAR, Alessandra. Páginas de sensação: Literatura popular e pornográfica no Rio de Janeiro (1870-1924). São Paulo: Companhia das Letras, 2004.

Crítica social e idéias médicas nos excessos do desejo: uma análise dos ñomances para homensò de finais do século XIX e início do XX. Cadernos Pagu, n. 28, jan./jun. 2007, p. 285-312.

Ao gosto do povo: as edições baratíssimas de finais do século XIXò. In: BRAGANÇA, Anibal; ABREU, Márcia (Orgs.). Impresso no Brasil: dois séculos de livros brasileiros. São Paulo: Editora UNESP, 2010, p. 89-99.

FOUCAULT, Michel História da sexualidade 1: A vontade de saber. 5.ed. Trad. Maria Thereza da C. Albuquerque e J. A. Guilhon Albuquerque. Rio de Janeiro: Edições Graal, 1984a.

História da sexualidade 2: O uso dos prazeres. Trad. Maria Thereza da C. Albuquerque. Rio de Janeiro: Edições Graal, 1984b.

História da sexualidade 3: O cuidado de si. 12. ed. Trad. Maria Tereza da Costa Albuquerque. Rio de Janeiro: Edições Graal, 2013.

FREUD, Sigmund. Três ensaios sobre a sexualidade. In: Obras psicológicas completas de Sigmund Freud. Vol. VII. 2. ed. Rio de Janeiro: Imago, 1989 [1905].

HALLEWELL, Laurence. O livro no Brasil: Sua História. Trad. Maria da Penha Villalobos, Lólio Lourenço de Oliveira e Geraldo Gerson de Souza. 2. ed. rev. e ampl. São Paulo: Editora Da Universidade de São Paulo, 2005.

HODGART, Matthew John Caldwell. Satire: origins and principles. New Brunswick (U.S.A.) and London (U.K.): Transaction Publishers, 2010.

HUNT, Lynn. A invenção da pornografia: obscenidade e as origens da modernidade. São Paulo: Hedra, 1999.

MAINGUENEAU, Dominique. O discurso pornográfico. Trad. Marcos Marcionilo. São Paulo: Parábola Editorial (Série Lingua [gem], n. 42), 2010.

MENDES, Leonardo. Livros para homens: sucessos pornográficos no Brasil no final do século XIX. In: Cadernos do IL, Porto Alegre, n. 53, jan. 2016, p. 173-191.

MOISÉS, Massaud. Dicionário de termos literários. 4. ed. São Paulo: Cultores, 1985.

MONIZ, Fábio Frohwein de Salles. Laurindo Rabelo: cadeira 26, patrono 2. ed. Rio de Janeiro: Imprensa Oficial de São Paulo, 2012. (Série Essencial, n. 9, Academia Brasileira de Letras).

RABELAIS (pseud. de Alfredo Gallis). A história de cada uma: os serões do convento, s/d.

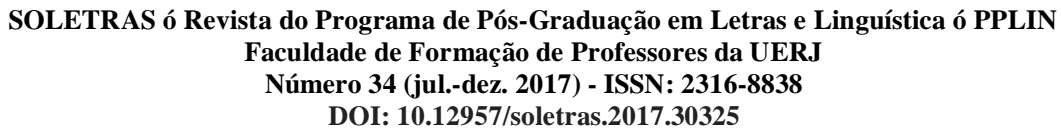


REBELLO, Laurindo José da Silva. Obras poéticas livres. Rio de Janeiro, 1882.

VENTURA, António. Posfácio ï ñRabelaisò, isto é, Alfredo Gallis, o pornógrafo. In: RABELAIS (pseud. de Alfredo Gallis). Aventuras Galantes. Coordenador da coleção e posfácio de António Ventura. Lisboa: Tinta-da-China, 2011.

ZILBERMAN, Regina. Literatura de rodapé (ou) o jornal como suporte literário. In: Ideias, Jornal do Brasil, 8 de novembro de 2003. Disponível em <http://www2.metodista.br/unesco/hp_unesco_redealcar36completo.htm>. Acessado em 26/05/2014.

\title{
Fontes periódicas
}

Coió (O). Rio de Janeiro. 1901-1902.

Gazeta de Notícias. Rio de Janeiro. 1875-1956.

Marmota Fluminense (A). Rio de Janeiro. 1852-1857.

Rio $N u(O)$. Rio de Janeiro. 1898-1916.

Riso (O). Rio de Janeiro. 1911-1912.

\section{THROUGH THE KEYHOLE: authors and works of the Luso-Brazilian pornographic literature (1890-1912)}

\begin{abstract}
The present article aims to recover type of writing silenced by the history of literature, the "romance for men", and some authors who circulated pornographic works in books and newspapers in Brazil in the Eighteenth Century, besides recognizing, in the heteroclite construction of this book scenario, in the nineteenth century, the plurality of literary productions and the diversity of reading practices. This literature was best-seller such that many other printers / booksellers ventured into this era that uncovered the most intimate desires of Brazilian readers of the late nineteenth century. To this purpose, we will rely on the theoretical postulates of Cultural History and on the researches in primary texts that contribute to the construction of the representation of a reading community of the late nineteenth century. Thus, we can contribute to the construction of the history of literature and rescue the senses of the terms used for pornographic novels, in addition to indicate some books of this genre, which circulated in Brazil in the late nineteenth century and early twentieth century.
\end{abstract}

Keywords: Pornographic literature. Eighteenth-century Literature. Forgotten books and authors.

Recebido em: 06 de setembro de 2017 .

Aprovado em: 26 de outubro de 2017. 